\title{
SŁowo OD REDAKTORA
}

\section{Tomasz Gąsowski}

Motywem przewodnim kolejnego numeru „Sowińca” są losy ludzi, których możemy nazwać bez nadmiernej przesady ,cichymi bohaterami naszej niepodległości”. Walka o niepodległość jest zawsze wysiłkiem zbiorowym, udziałem grup, środowisk czy organizacji. Czasami, jak to miało miejsce w przypadku dziewiętnastowiecznych Polaków, była ona udziałem kilku pokoleń. Zdarzały się także heroiczne czyny jednostek, wywierające wpływ na współczesnych i wpisujące się w pamięć potomnych.

Zbiorowy wysiłek bojowników o niepodległość jest jednak zawsze sumą działań poszczególnych ludzi, z których każdy wniósł do niego wkład na własna miarę. Nie sposób wszystkich wymienić, ocenić czy uczcić. Ale warto przywrócić pamięć przynajmniej o niektórych. Taka właśnie intencja przyświecała redaktorom niniejszego numeru naszego periodyku.

Na jego kartach spotykamy więc kilka postaci, których życie i dokonania w służbie niepodległości zostały w całości lub we fragmentach przypomniane przez naszych autorów. Uczynili to w tekstach opatrzonych solidną bibliografią i zawierających wartościowe aneksy źródłowe. Tę krótką z konieczności listę otwiera zatem zarys sylwetki Kazimiery Jagniewskiej, młodej lwowskiej harcerki, reprezentantki znakomitego, patriotycznego pokolenia młodzieży wychowanego w II Rzeczpospolitej, zamordowanej przez sowietów w czerwcu 1941 r. Dalsze strony „Sowińca” przynoszą pierwszą część wojennej biografii (kolejne w przygotowaniu) niewiele starszego od niej człowieka, którego również uformowała cywilna i wojskowa edukacja w niepodległej Polsce. Polsce, której służył następnie w latach okupacji, a także po zakończeniu wojny, broniąc jej przed komunistycznym zniewoleniem. To gen. Bolesław Michał Nieczuja-Ostrowski, legendarny „Tysiąc”. I wreszcie poznajemy fragment wojennych losów przedstawiciela starszej generacji, uczonego, psychologa, pedagoga i lekarza, ale także żołnierza, uczestnika trzech wojen, prof. Stefana Szumana. Autor przedstawił tu działalność swego bohatera w szeregach Armii Krajowej.

Kolejny tekst przenosi nas w czasy bliższe, lat 80. ubiegłego stulecia. Najważniejszym orężem podziemnej „Solidarności” w jej walce o wolność było słowo, ulotka, gazeta, czasopismo czy książka. Funkcjonowanie niezależnego obiegu było dziełem wielu tysięcy ludzi, dziennikarzy i publicystów, pisarzy, redaktorów, wydawców, drukarzy 
i kolporterów. Skupiali się oni wokół setek podziemnych wydawnictw. Historię jednego z nich, działającego w Krakowie Wydawnictwa Myśli Nieinternowanej, nakreślił jego inicjator i twórca Tomasz Gugała. Przedstawił w swym tekście, który uznać można za swoisty raport końcowy, ludzi związanych z WMN i ich dokonania, a także dramatyczne niekiedy wydarzenia towarzyszące działalności wydawniczej.

Numer zamykają jak zwykle dokumenty. Są to dwa materiały źródłowe o charakterze wspomnieniowym. Pierwszy, opracowany przez Jana Brzeskiego, to pochodzące ze zbiorów majora Czesława Eugeniusza Blicharskiego, postaci dobrze znanej stałym czytelnikom „Sowińca”, Wspomnienia Tarnopolan. Cz. Blicharski był niestrudzonym kronikarzem i dokumentalistą swych stron rodzinnych, Tarnopola i ziemi tarnopolskiej - utraconej ojczyzny wielu Polaków. Autor drugiego ze wspomnień, Władysław Andrzej Chudy, przywołuje interesujący a mało znany epizod związany $\mathrm{z}$ funkcjonowaniem w emigracyjnym Londynie do połowy lat 60 . XX w. organizacji „Pogoń”. Zajmowała się ona szkoleniem wojskowym młodych Polaków w celu przygotowania ich do przyszłej walki o niepodległość. Autor przywołuje opis kursu spadochronowego odbywającego się na terenie Francji.

Życząc interesującej i pożytecznej lektury, zachęcam do sięgnięcia po 44 numer „Sowińca” i zapowiadam kolejne.

Kraków, maj 2014 r. 